Allergic Diseases and the Environment 
Nestlé Nutrition Workshop Series

Pediatric Program, Vol. 53

\section{Allergic Diseases and the Environment}

Editors

Erika Isolauri, Turku, Finland

W. Allan Walker, Boston, Mass., USA

19 figures and 31 tables, 2004

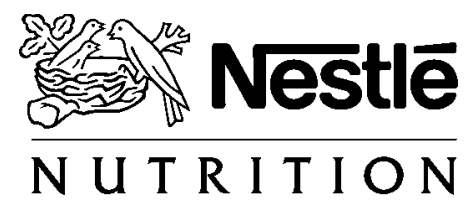




\section{Nestec Ltd., 55 Avenue Nestlé, CH-1800 Vevey (Switzerland) S. Karger AG, P.O. Box, CH-4009 Basel (Switzerland) www.karger.com}

(C) 2004 Nestec Ltd., Vevey (Switzerland) and S. Karger AG, Basel (Switzerland). All rights reserved. This book is protected by copyright. No part of it may be reproduced, stored in a retrieval system, or transmitted, in any form or by any means, electronic, mechanical, photocopying, or recording, or otherwise, without the written permission of the publisher.

Printed in Switzerland on acid-free paper by Reinhardt Druck, Basel

ISBN 3-8055-7649-8

ISSN 0742-2806

\section{Library of Congress Cataloging-in-Publication Data}

(CIP-Code is available from the Library of Congress on request.)

The material contained in this volume was submitted as previously unpublished material, except in the instances in which credit has been given to the source from which some of the illustrative material was derived.

Great care has been taken to maintain the accuracy of the information contained in the volume. However, neither Nestec Ltd. nor S. Karger AG can be held responsible for errors or for any consequences arising from the use of the information contained herein. 


\section{Contents}

VII Preface

XI Foreword

XIII Contributors

1 Clinical Overview: The Changing Pattern of Clinical Aspects of Allergic Diseases

Vandenplas, Y. (Brussels)

27 Changing Definitions of Allergy

Bindslev-Jensen, C. (Odense)

33 The Changing Prevalence and Clinical Profile of Food Allergy in Infancy

Hill, D.J.; Heine, R.G.; Hosking, C.S. (Melbourne)

53 The Hygiene Hypothesis: Modulation of the Atopic Phenotype by Environmental Microbial Exposure Holt, P.G. (Perth)

69 Allergy: Is It a Th2-Predominant Disease? Pro Romagnani, S. (Florence)

97 The Induction of Immunoregulation Prevents the Development of Immunopathology in Chronic Helminth Infections and Allergy van den Biggelaar, A.H.J.; Yazdanbakhsh, M. (Leiden)

117 Mechanisms Governing Non-Responsiveness to Food Proteins

Nagler-Anderson, C.; Walker, W.A. (Charlestown, Mass.) 
133 Oral Tolerance and Gut Maturation

Murch, S. (London)

153 The Role of Bacteria in the Development of Intestinal Protective Function

Nanthakumar, N.N.; Walker, W.A. (Charlestown, Mass.)

179 Human Colonic Microbes: Ecology, Physiology and Metabolic Potential of Intestinal Bacteria

Macfarlane, G.T.; Macfarlane, S. (Dundee)

199 Does Breast-Feeding Protect from Allergies?

Bergmann, R.L.; Bergmann, K.E.; Dudenhausen, J.W. (Berlin)

217 Protective Nutrients and Gastrointestinal Allergies

Duggan, C. (Boston, Mass.)

251 Identification of Probiotics and Prebiotics with Antiallergenic Properties

Salminen, S.; Isolauri, E. (Turku)

267 Can We Prevent the Allergic Child from Becoming a Chronic Asthmatic Adult?

Liu, A.H. (Denver, Colo.)

285 The German Infant Nutritional Intervention Study (GINI): A Model for Allergy Prevention von Berg, A. (Wesel)

301 Novel Approaches for the Nutritional Management of the Allergic Infant

Isolauri, E. (Turku)

315 Concluding Remarks

319 Subject Index 


\section{Preface}

A major pediatric health problem in developed countries is the increasing incidence of allergic diseases during infancy and childhood. Over the last two decades the incidence of atopic dermatitis and asthma has increased several fold and represents a major cause of medical expense, hospitalization, and loss of school/work days for children and their parents. Paradoxically, the incidence of allergic disease has not risen in developing countries over the same time period. This observation has led to careful scrutiny of the environmental differences that exist between the two settings and may account for this discrepancy. As a result of this scrutiny, a hypothesis, the 'hygiene hypothesis', has evolved which suggests that infants born in the 'sterile' environment of modern hospitals in the developed world may not be subjected to the same microbial burden on entering the extrauterine environment as their counterparts in a contaminated setting in the developing world. Therefore, these infants in a 'sterile' environment with a lack of microbial stimulus may not adjust to a balanced mucosal immune response which includes expansion of T-helper (Th) cell subsets that can mediate immune responses (e.g., cellular immune, humoral immune, and oral tolerance). Accordingly, this Workshop was convened to consider in depth the environmental factors that influence the changing pattern of worldwide childhood allergy. Experts in basic research, epidemiology, and clinical investigation from around the world have been asked to provide their perspectives on this dilemma.

The conference began with a clinical overview of the changing patterns in the clinical aspects of pediatric allergic disease. What emerged was the notion of 'the allergic march'. This suggests that once the infant is sensitized there is a progression of sensitization. This concept also suggests that 'allergyprone' infants will develop clinical symptoms largely based on the nature and route of allergen exposure throughout infancy and childhood. For example, food allergy from the ingestion of foreign proteins in breast milk or formula initially results in gastrointestinal and/or skin manifestations of allergy. As the infant gets older, inhalant allergens become important and result in pulmonary symptoms, with the end result being chronic asthma. The concept further suggests that once sensitized the infant/child may have a progression 
of allergy leading to a chronic condition. This suggestion, however, has not been proven by clinical studies. A new definition of hypersensitivity was considered and the notion that symptoms ascribed to allergy are not always immunologically mediated and must be carefully evaluated before labeling of an 'atopic' child is made. Clarification between the term 'atopy' and allergy (hypersensitivity) was made. A strong suggestion for a better understanding of the mechanisms in order to distinguish between the terms is needed. Finally a careful appraisal of clinical manifestations of food allergy was considered in the context of an accurate diagnosis and possible strategy for prevention.

In a session on environmental factors contributing to the increased incidence of allergy in infants and children in developed countries, a refinement of the 'hygiene hypothesis' was presented. Careful clinical studies in IgE-mediated allergic infants and children, beginning at birth and prospectively followed, suggest that allergic children take longer to balance their ' $T$ '-helper cell subset response and therefore appear to be more prone to a Th2 (e.g., IgE-mediated) immune response to antigens (allergens). An appropriate initial colonization of the gut may help to prevent this developmental process. Strong evidence that allergy in infants and children was due to an imbalance in Th2 responsiveness was provided, making 'allergy' a Th2-predominant disease. However, by way of considering other mechanisms, clinical studies in African children infested with parasites, an IgE/Th2-mediated response, also appear to be protective against clinical allergic symptoms. These studies suggested that antiinflammatory cytokines induced by parasite infestation may prevent allergic symptoms.

An important component of the immune response to luminal antigens is the 'muted' systemic response to innocuous antigens such as food proteins and commensal flora, a process called oral tolerance. The current understanding of how this response occurs was discussed and the importance of commensal intestinal flora and innate immune responses underscored. The importance of breast-feeding in modulating an appropriate initial colonization of the neonatal gut was stressed with regard to oral tolerance and gut maturation. In the absence of an appropriate initial colonization, the infant may lack tolerance and inappropriately respond to innocuous antigens in the gut. To further emphasize the importance of the initial colonization process, the role of colonizing bacteria in the maturation of intestinal defenses and their effect in age-related neonatal intestinal infections were considered. 'Cross-talk' between colonizing bacteria in the developing epithelium response to bacterial components was discussed. In addition, new techniques for more precisely defining the myriad of colonizing gut bacteria and the need to examine microbial intestinal contents with feeding was reviewed. Of interest was the observation that partial hydrolysates fed to infants at risk of developing allergy produced a gut flora that was more similar to breast-fed infants' flora than infants fed standard infant formulas. 
Finally, we considered whether breast-feeding or protective nutrients fed to infants at risk of developing allergy could prevent or modulate the severity of allergic symptoms. Careful meta-analyses showed that exclusive breastfeeding did not appear to prevent allergy but was protective during nursing. There was also some suggestion of a delay in expression of allergic symptoms in infants on breast milk. Standard protective nutrients such as glutamine, arginine, nucleotides, etc., did not appear to protect infants at risk of allergy. However, a warning was given that using too restrictive a diet in treating infants at risk of developing allergy could lead to severe malnutrition and other complications. Evidence suggested that probiotics, but not prebiotics, may be effective in preventing allergy. This was followed by strong evidence, provided by a carefully considered clinical trial in infants at risk of developing allergy, that probiotics given to the mother in late pregnancy and continued while nursing infants in conjunction with the infants receiving the same probiotic could effectively prevent allergic dermatitis. Other attempts to prevent chronic asthma by early intervention suggested that more prospective multicenter trials are needed. An excellent prospective multicenter trial in Germany, the GINI study, suggests that partial hydrolysates can delay and possibly prevent long-term manifestations of allergy. However, this study needs to be carried out over a longer time period before definitive conclusions can be made.

In general, the comprehensive approach to the environment and clinical allergy was very helpful in answering questions and clarifying concepts for the attendees. However, probing observations from the attendees with extensive clinical experience suggest that additional long-term, multicenter trials are necessary before an approach to reversing this increasing trend in pediatric allergic disease can be made. 


\section{Foreword}

For this 53rd Nestlé Pediatric Nutrition Workshop, the topic 'Allergic Diseases and the Environment' was chosen as a follow-up to two previous workshops with similar topics, held in 1987 in Munich, Germany ('Food Allergy') and in 1993 in Versailles, France ('Intestinal Immunology and Food Allergy'). However, since then, the evolution and incidence of allergic diseases have changed and there have been many successful advances in the prevention and therapy of allergic diseases. Therefore, it seemed necessary to point out the state-of-the-art of environmental influences upon allergic diseases. With this Workshop, we wanted to determine whether the hygiene hypothesis really would explain some mechanisms in the development of allergic diseases. In addition, how promising are the attempts to enhance oral tolerance and how effective are antioxidants, polyunsaturated fatty acids, pre- and probiotics in the prevention and treatment of allergic diseases? In order to answer these and other questions we sought the knowledge of various experts in different fields to clarify the pathogenesis of and the preventive as well as therapeutic implications for the various manifestations of the atopic syndrome.

I would like to thank the two chairmen, Prof. Erika Isolauri and Prof. Allan Walker, who are well-known experts in this field, for putting the program together and inviting as speakers the opinion leaders in the field of allergic diseases. Pediatricians invited from 21 countries contributed to the discussions that are published in this book.

We wish to thank Dr. Philippe Steenhout from the Nutrition Strategic Business Division (NSBD), Lausanne, Switzerland, who was responsible for the scientific coordination of the Workshop. Our special thanks to the administrative team of the NSBD and the Nestlé Research Center (NRC) for the successful relocation and organization of the Workshop, which should originally have been held in Kuala Lumpar, Malaysia. The last-minute relocation to the NRC in Vers-Chez-les-Blancs, Lausanne, was deemed necessary due to the fear of potential terrorist attacks arising from the war in Iraq.

Prof. Wolf Endres, MD

Vice-President

Nestec Ltd., Vevey, Switzerland 


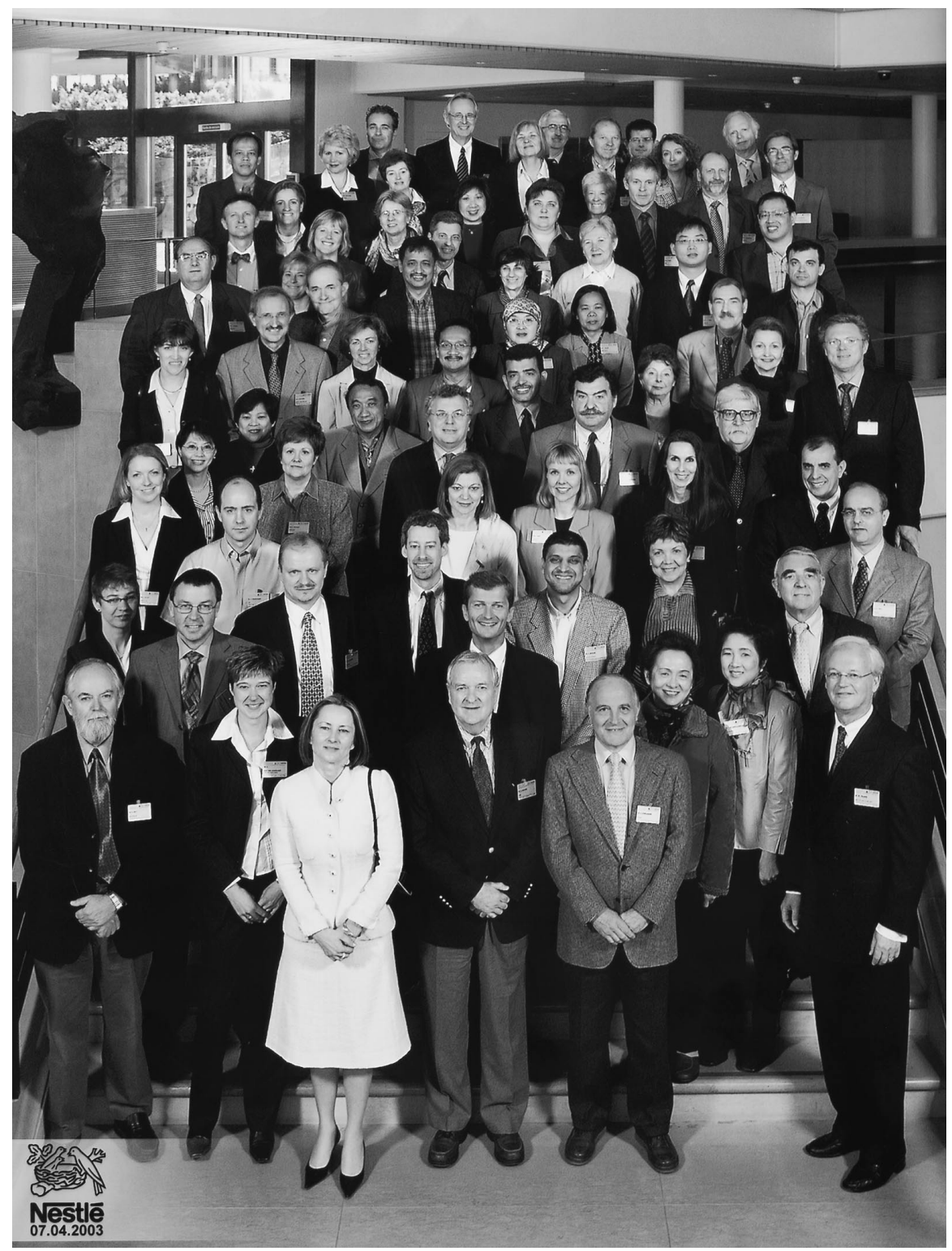

53rd Nestlé Nutrition Workshop

Pediatric Program

Lausanne, April 6-10, 2003 


\section{Contributors}

\section{Chairpersons, Speakers}

\section{Prof. Peter Van Bladeren}

Nestlé Research Center

Management

PO Box 44

CH-1000 Lausanne 26

Tel. +41217858801

Fax +41217858555

E-Mail peter.van-bladeren@

rdls.nestle.com

\section{Prof. Renate L. Bergmann}

Klinik für Geburtsmedizin

Charité Virchow Hospitals

Humboldt University

Augustenburger Platz 1

DE-13353 Berlin

Germany

Tel. +4930450564101

Fax +4930450564908

E-Mail renate.bergmann@charite.de

\section{Prof. Carsten}

\section{Bindslev-Jensen}

Odense University Hospital

Allergy Center

DK-5000 Odense C

Denmark

Tel. +4565413624

Fax +456312 1507

E-Mail carsten.bindslev-jensen@

allergi.sdu.dk

\section{Dr. Christopher Duggan}

Children's Hospital

Division of GI/Nutrition

300 Longwood Avenue

Boston, MA 02115

USA

Tel. +1 6173557612

Fax +1 6177300496

E-Mail christopher.duggan@

tch.harvard.edu

\section{Dr. David Hill}

Department of Allergy

Royal Children's Hospital

Flemington Road

Parkville, Victoria 3052

Australia

Tel. +61 393455701

Fax +61 93454848

E-Mail allergy.clinic@rch.org.au

\section{Prof. Patrick Holt}

Division of Cell Biology

Telethon Institute for Child Health

Research

PO Box 855

West Perth WA 6872

Australia

Tel. +61 894897838

Fax +61 894897707

E-Mail patrick@ichr.uwa.edu.au 


\section{Prof. Erika Isolauri}

Turku University Central Hospital University of Turku

Department of Paediatrics

FI-20520 Turku

Finland

Tel. +358 23131460

Fax + 35823132433

E-Mail erika.isolauri@utu.fi

\section{Dr. Simon Murch}

Royal Free and University College Medical School

Centre for Paediatric

Gastroenterology

Royal Free Campus

Rowland Hill Street

London NW3 2PF

UK

Tel. +44 207830 2780/830 2779

Fax +442078302146

E-Mail s.murch@rfc.ucl.ac.uk

\section{Prof. Sergio Romagnani}

Università degli Studi di Firenze

Dipartimento di Medicina Interna

Viale Morgagni, 85

IT-50134 Florence

Italy

Tel. +39 55 413663/4296402

Fax +3955 412867

E-Mail s.romagnani@dmi.unifi.it

\section{Prof. Seppo Salminen}

University of Turku

Degree Programme on

Healthbiosciences

(Functional Foods Forum)

FI-20014 Turku

Finland

Tel. +358 400601394

Fax +35823336884

E-Mail seppo.salminen@utu.fi

\section{Dr. Anita van den} Biggelaar

Leiden University Medical Center Department of Parasitology-4

Albinusdreef 2

PO Box 9600

NL-2300 RC Leiden

The Netherlands
Tel. +3171526 5062/5135814

Fax +31 715266907

E-Mail biggelaar@lumc.nl

\section{Prof. Yuan Vandenplas}

Free University of Brussels

Academic Hospital

Department of Pediatrics

Laarbeeklaan 101

BE-1090 Brussels

Belgium

Tel. +3224775780

Fax + 3224775783

E-Mail yvan.vandenplas@az.vub.ac.be

\section{Dr. Andrea von Berg}

Marien-Hospital GmbH

Forschungsinstitut zur Prävention

von Allergien und

Atemwegserkrankungen

Kindes- und Jugendalter der Klinik

für Kinder- und Jugendmedizin

Pastor-Janssen-Strasse 8-38

DE-46483 Wesel

Germany

Tel. +49 281104 1664/1659

Fax +492813191659

E-Mail vonBerg@

marien-hospital-wesel.de

\section{Prof. W. Allan Walker}

Harvard Medical School

Massachusetts General Hospital - East

Developmental Gastroenterology

Laboratory

Charlestown, MA 02129

USA

Tel. +1 6177267988

Fax +1 6177264172

E-Mail allan_walker@

hms.harvard.edu 


\section{Moderators}

\section{Dr. Rodolphe Fritsche}

Nestlé Research Center

Food Immunology

P.O. Box 44

1000 Lausanne 26

Switzerland

Phone: ++41 217858683

Fax: ++41217858544

E-mail:

rodolphe.fritsche@rdls.nestle.com

\section{Dr. Pierre Guesry}

Nestlé Research Center

Scientific and General Services

P.O. Box 44

1000 Lausanne 26

Switzerland

Phone: ++41217858090

Fax: ++41217858308

E-mail:

pierre.guesry@rdls.nestle.com

\section{Dr. José Saavedra}

Nestlé Glendale

800 N. Brand Blvd.

91203 Glendale

USA

Phone: + 1 (818) 549-6774

Fax: + 1 (818) 549-5704

E-mail: jose.saavedra@us.nestle.com

\section{Dr. Eduardo Schiffrin}

Nestlé Research Center

NSBD Medical Services

P.O. Box 44

1000 Lausanne 26

Switzerland

Phone: + +4121785 8671

Fax: ++41217858565

E-mail:

eduardo.schiffrin@rdls.nestle.com

\section{Dr. Philippe Steenhout}

Nestlé Research Center

NSBD Medical Services

P.O. Box 44

1000 Lausanne 26

Switzerland

Phone: + +41217859547

Fax: ++41217858565

E-mail:

philippe.steenhout@rdls.neste.com

\section{Dr. Thierry von der Weid}

Nestlé Research Center

Food Immunology

P.O. Box 44

1000 Lausanne 26

Switzerland

Phone: + +41219243007

E-mail:

Thierry.VonDerWeid@nestle.com

\section{Invited attendees}

Prof. Magda Carneiro-Sampaio / Brazil Prof. Emanuel Sarinho / Brazil

Prof. Dirceu Sole / Brazil

Dr. John Dean / Canada

Dr. Antony Ham Pong / Canada

Dr. Peter Nieman / Canada

Mrs. Lesley Scharf / Canada

Prof. Carl-Peter Bauer / Germany

Dr. Chen Chun-Yi / Great China

Region (Taiwan)

Dr. Ni Yen-Hsuan / Great China

Region (Taiwan)

Dr. Shyur Shyh-Dar / Great China

Region (Taiwan)
Prof. Evangelia Mantzourani / Greece Prof. Santa Nousia Arvanitaki / Greece Dr. Photini Saxoni-Papageorgiou /

Greece

Dr. Konstantinos Siafakas / Greece

Dr. Eva Micskey / Hungary

Dr. Anky Tri Rini Kusumaning Edhy /

Indonesia

Dr. Anang Endaryanto / Indonesia

Dr. Yusmala Helmy / Indonesia

Dr. Zakiudin Munasir / Indonesia

Dr. Budi Setiabudiawan / Indonesia

Dr. Dadi Suyoko / Indonesia

Prof. Antonio Marini / Italy 
Dr. Rinaldo Zanini / Italy

Prof. Salim Al-Malik /Kingdom of Saudi Arabia

Mrs. Yolanda Meijer / The Netherlands

Mr. Herman Neijens / The Netherlands

Mrs. Johanna Rijntjes / The Netherlands

Dr. Pilar Agnes Andaya / Philippines

Dr. M.A. Stella Paspe / Philippines

Prof. Mieczyslawa Czerwionka-Szaflarska /

Poland

Dr. Hanna Szajewska / Poland

Prof. Coriolan Ulmeanu / Romania

Prof. Vera Revyakina / Russia

Dr. Ahmed Ismail Manjra / South Africa

Prof. Luis Ros Mar / Spain

Prof. Juan Carlos Vitoria Cormenzana /

Spain

Dr. Christina West / Sweden

Prof. Chalerat Direwattanachai / Thailand

Prof. Jarunghchit Ngamphaiboon /

Thailand

Dr. Jonathan Hourihane / UK

Dr. Gideon Lack / UK

Prof. Lesia Besh / Ukraine

Prof. Olga Lasytsya / Ukraine

Prof. Ricardo Sorensen / USA

\section{Nestlé participants}

Mrs. Lesley Scharf / Canada

Prof. Mike Possner / Germany

Mr. Elias Papadopoulos / Greece

Dr. Gabriella Metzger / Italy

Mrs. Marjan Skotnicki-Hoogland /

The Netherlands

Dr. Olga Netrebenko / Russia

Prof. Wolf Endres / Switzerland

Dr. Bianca-Maria Exl-Preysch /

Switzerland

Mr. Rodolphe Fritsche / Switzerland

Dr. Pierre Guesry / Switzerland

Ms. Petra Klassen / Switzerland

Mrs. Florence Rochat / Switzerland

Dr. Eduardo Schiffrin / Switzerland

Ms. Marie-Christine Secretin /

Switzerland

Dr. Philippe Steenhout / Switzerland

Dr. Thierry von der Weid / Switzerland

Dr. Janet Aylott / UK

Mrs. Cynthia Brown / USA

Mrs. Linda Hsieh / USA

Prof. Pepe Saavedra / USA 